\title{
Welcome to this online edition
}

Philip Wiffen

I am delighted to present this onlineonly issue of the European Journal of Hospital Pharmacy (EJHP). The success of the journal in recent years has meant that the quantity and quality of submissions has risen considerably. This is a great demonstration of the progress of a research mentality among hospital pharmacists and bodes well for the future.

Even with a healthy rejection rate of above $60 \%$, articles can be delayed for

Correspondence to Professor Philip Wiffen, Pain Research Unit, Churchill Hospital, Oxford, UK; pwiffen@ oxfordsrs.org.uk
10 months or more before appearing in print. An online version reduces the backlog to some extent and while authors will not see their articles in print, their research is made more visible by allowing readers to access the full article for a period of time after publishing the online-only version.

This issue of some 200 pages showcases the range of studies regularly published in EJHP and in this case focuses on a range of activities of hospital pharmacists as well as some country-specific reports. I hope you will enjoy browsing through the articles, find some that are relevant to your practice and be inspired to publish your own work in this journal.

Funding The authors have not declared a specific grant for this research from any funding agency in the public, commercial or not-for-profit sectors.

Competing interests None declared.

Patient consent for publication Not required.

Provenance and peer review Commissioned; internally peer reviewed.

(c) European Association of Hospital Pharmacists 2021. No commercial re-use. See rights and permissions. Published by BMJ.

A) Check for updates

To cite Wiffen P. Eur J Hosp Pharm 2021;28:e1.

Eur J Hosp Pharm 2021;28:e1.

doi:10.1136/ejhpharm-2021-003107

ORCID iD

Philip Wiffen http://orcid.org/0000-0001-6085-1307 